\title{
FORTUNATO DE SELGAS Y SAN JULIÁN DE LOS PRADOS. LA SÍNTESIS DEL DEBATE DE LA RESTAURACIÓN MONUMENTAL EN ESPAÑA A PRINCIPIOS DEL SIGLO XX
}

\author{
María Pilar García Cuetos ${ }^{1}$ \\ Universidad de Oviedo
}

\begin{abstract}
La actuación de Fortunato de Selgas en San Julián de los Prados, Oviedo, sintetiza el debate sobre la restauración monumental en España a principios del siglo XX. Integra elementos de la restauración estilística, limitada por el racionalismo arqueológico, el avance de las teorías italianas de la restauración histórica y boitiana y la influencia de la estética ruinista y de la llamada sinceridad arqueológica. Unas fotografías inéditas de 1932 nos devuelven la imagen perdida de la iglesia tras la intervención y nos permiten conocer uno de los ejemplos más interesantes de la restauración española de principios del siglo XX, desgraciadamente alterado por intervenciones posteriores.
\end{abstract}

Palabras clave: Restauración monumental; prerrománico asturiano; Fortunato de Selgas; John Ruskin.

\section{FORTUNATO DE SELGAS AND SAN JULIÁN DE LOS PRADOS. SUMMARY OF THE DEBATE ABOUT HERITAGE RESTORATION IN SPAIN AT THE BEGINNING OF THE $2^{\text {th }}$ CENTURY}

The restoration by Fortunato de Selgas in San Julián de los Prados summarises the debate about heritage restoration in Spain at the beginning of the $20^{\text {th }}$ century. It integrates a combination of elements from restoration in style limited by archaeological rationalism, the progress of Italian historical and Boitian theories, and the influence of Ruinist aesthetics together with the so-called archaeological sincerity. Several unpublished photographs dated in 1932 return the lost image of the church after the intervention and allow us to know one of the most interesting examples of Spanish restoration at the beginning of the $20^{\text {th }}$ century, unfortunately altered by following interventions.

Key words: monumental restoration; Asturian pre-Romanesque architecture; Fortunato de Selgas; John Ruskin.

Cómo citar este artículo / Citation: García Cuetos, María Pilar (2021) "Fortunato de Selgas y San Julián de Los Prados. La síntesis del debate de la restauración monumental en España a principios del siglo XX”. En: Archivo Español de Arte, vol. 94, núm. 373, Madrid, pp 33-50. https://doi.org/10.3989/aearte.2021.03

\section{Fortunato de Selgas. Un restaurador autodidacta}

Nacido en el seno de una familia acomodada, Fortunato de Selgas Albuerne (Cudillero, 1838-Madrid, 1921) [fig.1] estudió derecho, pero se inclinó por los estudios de arqueología², tal y como se los definía en aquel momento. En 1880 comenzó a publicar sus trabajos en revistas como Asturias Ilustrada y Cientifico-Literaria, Revista de Asturias, España, o el Boletín de la Sociedad Española de Excursiones. Fue nombrado miembro de la Real Academia de la Historia en 1885,

\footnotetext{
1 gcuetos@uniovi.es / ORCID iD: https://orcid.org/0000-0003-1221-5853

2 González/ Fernández, 1994: 275 y Manzanares, 1990: IX-XIV.
} 


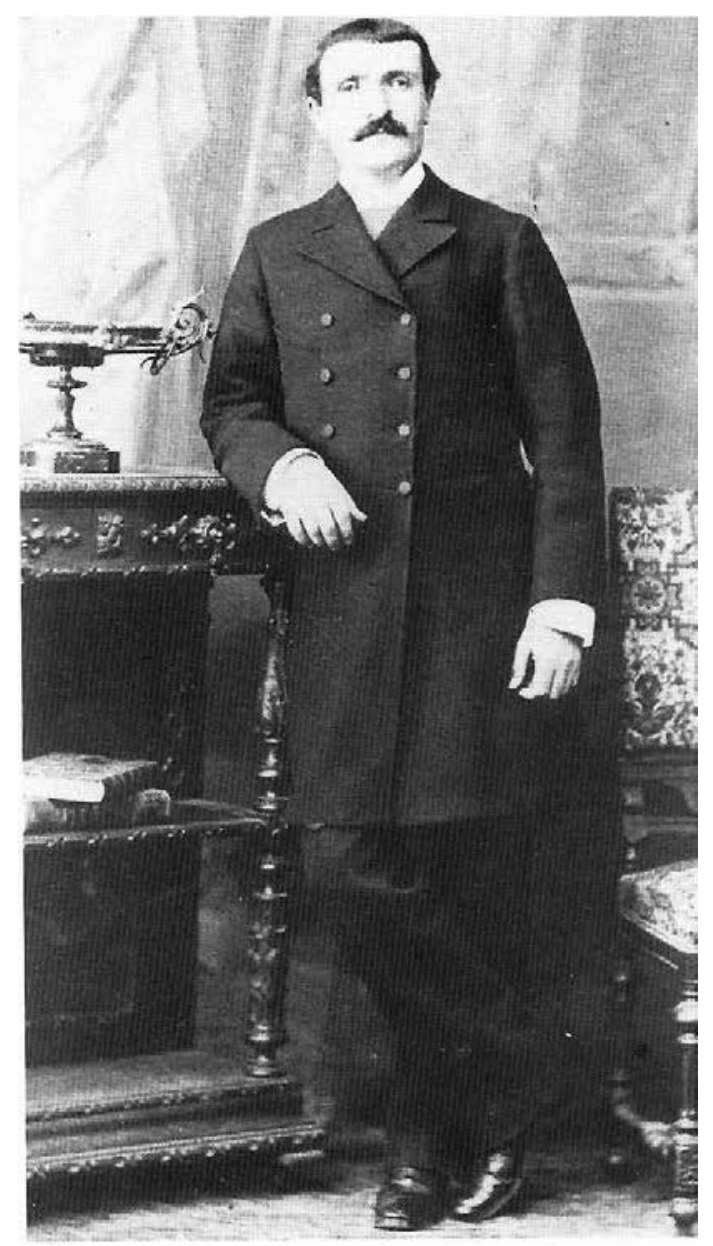

Fig. 1. Fortunato de Selgas. Fundación Selgas-Fagalde.

correspondiente de la de san Fernando en 1906 y de la de Bellas Artes y Ciencias Históricas de Toledo. Se vinculó a la Comisión Provincial de Monumentos de Oviedo y a la Academia de la Quintana, grupo de intelectuales empeñados en la recuperación del patrimonio cultural asturiano. Mantuvo una estrecha amistad con Fermín Canella, rector de la Universidad y su compañero en la Comisión y la Academia de la Quintana. Canella lo acercó también a los componentes del Grupo de Oviedo, formado por profesores de la universidad ovetense vinculados al Regeneracionismo y el krausismo ${ }^{3}$. y alentó su labor en pro del conocimiento y la recuperación de los monumentos asturianos y la promoción de instituciones como las Escuelas Selgas, un centro modelo con la voluntad de aplicar las tesis de la renovación educativa ${ }^{4}$.

Selgas fue un autodidacta rodeado de personajes muy relevantes que rompió los límites del contexto asturiano. Tuvo peso en el ambiente del Madrid culto de su época y llegó a ser nombrado director del Museo Nacional de Reproducciones Artísticas, cargo al que renunció. Su amplia biblioteca reúne autores como Auguste Choisy, José A. de los Ríos, Hippolyte Thaine, Josep Gudiol, Teophile Gautier, Paul Lacroix, Ferdinand de Dartein, François Guizot, Luigi Canina, Ludovico Vitet, Louis Batissier o José Pijoan. Conocía la obra de Viollet-le-Duc y de Vicente Lampérez, que fue su amigo. Mantuvo contacto epistolar con el arqueólogo francés Jean-Auguste Brutails. Viajó a Italia, donde se aplicaba el restauro storico y arqueológico y parece haber recibido también las ideas de Camilo Boito.

Los amplios conocimientos que adquirió y los intercambios que mantuvo le acercaron a la praxis de la restauración monumental en la que se evidencian esas influencias. Es especialmente interesante su contacto con Jean-Auguste Brutails, destacado representante del racionalismo arqueológico francés. Tanto Selgas como los miembros de la Comisión de Monumentos, procuraron despertar el interés de Brutails por el prerrománico asturiano y es posible que ese fuera el motivo que le impulsara a viajar a Asturias para conocer esos monumentos en 1908. Previamente, los comisionados le habían hecho llegar la primera publicación que se ocupó de esta singular arquitectura, obra de Inocencio Redondo. Selgas también envió a Brutails todos sus estudios sobre el prerrománico asturiano y especialmente la monografía que editó tras su restauración de Santullano. En el Fondo Brutails de la Biblioteca de la Universidad Michel de Montaigne. Bordeaux3 se conserva ese ejemplar dedicado ${ }^{5}$.

\footnotetext{
3 Capellán, 2002.

${ }^{4}$ González/ Fernández, 1994: 278.

5 Collections patrimoniales numérisées de Bordeaux Montaigne. Fonds Brutails. Identificador: RES 18528.
} 
Selgas se acercó a los estudios de François Auguste Choisy, quien introdujo en sus análisis la proyección axonométrica, especialmente vinculada a la visión de los espacios interiores ${ }^{6}$, que le resultaron útiles en la comprensión y descripción de los sistemas constructivos y la articulación espacial. Además, el método de Choysi tiene una especial aplicación en el análisis de edificios caracterizados por su compartimentación, como los de la alta edad media española. Por ello, Manuel Gómez-Moreno adoptó esta técnica representativa en su obra Iglesias Mozárabes ${ }^{7}$. Asimismo, la emplearon Doménech i Montaner, Lampérez, Puig i Cadafalch, y Juan Antonio Gaya Nuño ${ }^{8}$. La visión de Choisy permitió a Selgas acercarse a la comprensión del espacio y quizás eso explique su interés por la disposición interna de los edificios. Su análisis sobre la composición de la cabecera y el crucero de San Julián de los Prados determinó algunas de sus decisiones restauradoras, que le permitieron recuperar el volumen interno y el equilibrio entre los espacios del monumento.

\section{La teoría restauradora de Fortunato de Selgas, fiel exponente de la diversidad y riqueza del panorama restaurador hispano a principios del siglo $\mathrm{XX}$}

Selgas plasmó su teoría restauradora en la monografía que publicó sobre Santullano en 1916. Se trata de uno de los primeros textos de reflexión sobre la nueva metodología que se implantaba en España y que suponía una ruptura con la restauración estilística ${ }^{9}$, aunque el mismo Selgas se declarase seguidor de las tesis de Vicente Lampérez. Defensor a ultranza de la arquitectura medieval, denostó abiertamente las reformas, definidas por él como restauraciones, que los monumentos prerrománicos habían experimentado en el siglo XVIII. El que emplee el término restauración para referirse a estas estratificaciones históricas, pone de manifiesto que relacionaba toda alteración de los monumentos con el concepto de restauración. Asimismo, entró en el debate establecido entre los partidarios de mantener las metodologías de corte violletiano y quienes optaban por abrazar las nuevas teorías: "Las ideas manifestadas por los arqueólogos en los Congresos internacionales de Arquitectura últimamente celebrados, acerca de la restauración de los viejos monumentos arruinados o alteradas sus formas con adiciones posteriores a su construcción, son contradictorias, sin que hayan llegado a un acuerdo, a una conclusión definitiva" ${ }^{10}$. Ante la falta de un criterio unánime, se mostró partidario de los postulados de Lampérez y por ello se ha venido calificando su intervención en Santullano como estilística. Pero un análisis más detenido del mismo Lampérez y la localización de documentos fotográficos inéditos, nos permiten identificar nuevos matices de su intervención.

Aparte de la pervivencia de los postulados de Viollet-leDuc, de los que Lampérez fue, en principio, uno de los principales difusores, el panorama de la restauración española también se vio influenciado por las ideas de los arqueólogos franceses y por las de John Ruskin. La obra de este último se tradujo al castellano y al catalán a partir de 1900 y sus tesis tuvieron una gran influencia en pensadores progresistas, como Julián Besteiro, el desarrollo del modernismo, el nacimiento de la definida como sinceridad arqueológica y la difusión de la estética ruinista. En la restauración monumental, sus ideas contribuyeron a fundamentar la oposición a las restauraciones en estilo y al desarrollo de la escuela conservadora ${ }^{11}$.

Las ediciones traducidas de las obras de John Ruskin aparecieron en España a finales del siglo XIX y principios del siglo $\mathrm{XX}^{12}$. Las Siete Lámparas de la Arquitectura se tradujo en torno a

\footnotetext{
${ }^{6}$ Bryon, 2009: 47-49.

7 García, 2011.

${ }^{8}$ Girón, F. Javier / Gil, Ignacio J., 2009.

${ }^{9}$ Selgas, 1916: 1-5.

${ }_{10}$ Selgas, 1916: 2.

${ }^{11}$ García, 2019.

${ }^{12}$ Litvak, 1973: 211-220 y Rivera, 2008: 146.
} 
$1900^{13}$ y cuando Fernando Chueca Goitia hizo una reseña del teórico inglés, utilizó esa edición ${ }^{14}$. Además, se han identificado las siguientes traducciones: 1897, A Joy Forever con el título La belleza que vive de Atilio Fillier; 1901 antología de Ruskin de Cebriá de Montoliu; 1901 Los jardines de las Reinas de Pedro Corominas; 1903 edición en catalán de una selección de conferencias de Ruskin de Manuel Montoliu; 1906 antología de Edmundo González Blanco, coincidiendo con la alusión directa a la obra del autor inglés que hizo Lampérez ese mismo año; 1907 The Bible of Amiens de Manuel Cigés; 1907 Sesame and Lilies, traducido por Julián Besteiro y 1908 Unto this last de Manuel Cigés ${ }^{15}$. Además, he localizado otra traducción al catalán Els Lliris del Jardí de la Reina de Manuel Montoliu de $1909^{16}$. Pero, sin ninguna duda, la principal traductora de las obras de Ruskin al español fue Carmen de Burgos ${ }^{17}$, una de las más destacadas intelectuales de la España del momento.

Tal y como expone Litvak $^{18}$, el avance de la arqueología, la pervivencia de la estética ruinista y la difusión de las ideas de pensadores como Ruskin, contribuyeron a la aparición de un movimiento estético llamado exotismo arqueológico ${ }^{19}$. La sugestión de la decadencia de las civilizaciones pasadas marcó la cultura española de entresiglos y necesariamente influyó en la restauración monumental. La constatación y la sugestión de la decadencia del pasado, convirtieron sus testimonios en objetos preciosos que debían conocerse y conservarse y favoreció el afianzamiento de restauraciones menos recreadoras.

Según Javier Rivera ${ }^{20}$, la figura más cercana a las teorías de John Ruskin fue Benigno de la Vega Inclán y Flaquer, Marqués de la Vega Inclán y Comisario Regio de Turismo de Alfonso XIII, que aplicó sus tesis en la intervención del patio del Yeso de los Reales Alcázares de Sevilla, materializada por el arquitecto José Gómez Millán. La ligazón de las ideas de Vega Inclán con Ruskin ha sido ratificada por Ashworth y Howard, quienes lo consideran su discípulo ${ }^{21}$, si bien debemos tener en cuenta asimismo el contexto ruinista y el exotismo arqueológico para situar las ideas del Marqués en el panorama español del momento ${ }^{22}$.

Las ideas de John Ruskin también encontraron eco en Josep Puig i Cadafalch, quien, al hablar de la restauración de la catedral de la Seu D’Urgell, escribió:

Apartemos primeramente la idea de acabar la obra, construyendo hoy aquello que nunca existió. El resultado de estas restauraciones es conocido por una larga y triste experiencia. Docenas de monumentos restaurados por toda Europa por hombres inteligentísimos, arquitectos de gran saber arqueológico, demuestran que las épocas pasadas, como los muertos, no resucitan, y las obras ejecutadas con tal criterio son obras nuevas con escasa relación con la obra antigua que se ha querido restaurar. El monumento pierde así su valor histórico y deja de servir para la ciencia, desapareciendo como documento arqueológico. La solución en la que hoy convienen arquitectos y arqueólogos es la de no reconstruir, la de limpiar y reparar ${ }^{23}$.

Puig i Cadafalch repetía las ideas de Ruskin cuando afirmaba que el monumento, como los muertos, no puede ser resucitado y que con la restauración se crea una obra nueva. Pero al mismo tiempo propuso eliminar los recubrimientos barrocos de la catedral, trasladar el coro a la cabecera y reabrir sus galerías. Explicaba que todo ello debía llevarse a cabo basándose en el conocimiento del monumento y que no debía añadirse o reconstruirse aquello de lo que no se tenía certeza. De

\footnotetext{
13 Ruskin, 1900. La fecha de esta edición no es segura.

14 Chueca, 1984.

15 Litvak, 1990: 71.

16 García, 2019: 242.

17 Simón, 2010 / García, 2019.

18 Litvak, 1973: 211-220 y 1990: 245-257.

19 Litvak, 1985: 183-196.

20 Rivera, 1992: 53.

21 Ashworth / Howard, 1999: 144.

22 García, 2016: 151-161.

23 Puig i Cadafalch, 1918: 105.
} 
esa manera, integró en su pensamiento no solo el influjo de Ruskin, sino el del racionalismo arqueológico francés y las tesis de la restauración histórica de Luca Beltrami.

Por su parte, a la hora de atacar a los antirrestauradores, y con la obra de John Ruskin ya editada en España, Vicente Lampérez también tuvo presentes las tesis ruinistas y sus ideas:

En el aspecto «pintoresco» de una ruina está su belleza. ¿Hay nada más bello y poético que unos muros caídos, unas bóvedas hendidas y unas estatuas yaciendo en el suelo, todo cubierto de hiedra y jaramago? Debemos, pues, dejar perecer el monumento, sin intentar salvarlo. De otra, la conservación debe imponerse a la restauración: "Solución inglesa: «conservar, no restaurar». Es decir, no hacer más que lo absolutamente necesario para contener la ruina, sin rehacer nada. Es lo que pudiéramos expresar así: «higiene, no medicina ${ }^{24}$.

Es evidente que tanto Puig i Cadafalch, como Vicente Lampérez integraron las lecciones de la metodología de Viollet-le-Duc con las aportaciones de John Ruskin y el conocimiento de los monumentos propiciado por el avance de la arqueología, entendida como el estudio del legado del pasado, y que fundamentaba la idea de la restauración basada en el conocimiento histórico. En este sentido, Rivera afirma que Lampérez asimiló todas estas corrientes y que fue, junto a Puig i Cadafalch, un avanzado del racionalismo arqueológico ${ }^{25}$. Igualmente, en su defensa de una renovación de la arquitectura española basada en el conocimiento de su historia, se vinculó al movimiento regeneracionista y los partidarios de la Institución Libre de Enseñanza ${ }^{26}$. Ello le acercó a personajes como Cajal o Unamuno, quien por cierto también se sintió atraído por las ideas de Ruskin. Lampérez basó su conocimiento de la arquitectura del pasado en el método histórico-arqueológico desarrollado por Viollet-leDuc o De Caumont e integró las aportaciones de Choisy o Brutails ${ }^{27} \mathrm{y}$, siguiendo a Cloquet, estableció que los monumentos podían dividirse en muertos y vivos ${ }^{28}$.

Partidario, a priori, de recuperar la unidad de estilo, Lampérez estableció límites y se mostró más moderado que el teórico francés, tal y como han afirmado Navascués, Isac, Gallego y Rivera $^{29}$. En lo relativo a los añadidos y reformas, propuso que se eliminasen solamente aquellos que "desfigurasen" el monumento y que en caso de tener que recurrirse a las refacciones, debía prescindirse de toda invención y del gusto personal del restaurador. La unidad debía supeditarse al conocimiento positivo del edificio. Esa misma postura, como acabamos de comprobar, es la que adoptó Puig i Cadafalch al recomendar eliminar el recubrimiento decorativo barroco que

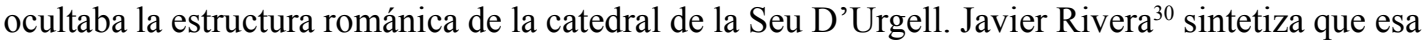
mixtura entre el posicionamiento a favor de la restauración estilística y la restauración histórica, sometida al límite del conocimiento histórico positivo del monumento, convierten a Lampérez en un defensor de una metodología híbrida a caballo entre Viollet-le Duc y Luca Beltrami. Además, no debe olvidarse, tal y como ha señalado Arrechea de Miguel, que en el panorama general de la restauración española del momento, el peso del avance de los estudios arqueológicos, entendidos como los relacionados con la historia de la arquitectura, contribuyó a favorecer la limitación de las restituciones estilísticas ${ }^{31}$. Por otro lado, Rivera señala que Lampérez debía conocer las ideas de Camilo Boito ${ }^{32}$, ya que también habría integrado alguno de sus postulados, como la necesidad de evidenciar las refacciones nacidas de la restauración.

Teniendo este referente muy claro, dada su estrecha relación con Lampérez, Fortunato de Selgas repitió sus planteamientos expuestos por primera en $1906^{33}$ y que aparecieron en sucesivos

\footnotetext{
24 Lampérez, 1906: 99.

25 Rivera, 2011: 60.

26 Rivera, 2011: 62.

27 Rivera, 2011: 64.

28 Rivera, 2011: 67-68.

29 Navascués, 1978. Isac, 1987. Rivera, 2011, Gallego, 2000.

30 Rivera, 2011: 69.

31 Arrechea, 1989: 160-161.

32 Rivera, 2011: 71-72.

33 Lampérez, 1906.
} 
trabajos hasta 1916. Selgas opuso restauradores y antirrestauradores y afirmó que quienes rechazan la restauración, defienden que "el monumento se ha de conservar y no restaurar, siendo preferible que se convierta en poética ruina cubierta de hiedra, a verle cambiado con renovaciones, que si están bien hechas, engañan, y si mal ejecutadas, perderá el edificio el carácter artístico y el atractivo que tienen las construcciones de otras Edades"34. Obviamente, está aludiendo a las tesis de John Ruskin. Bien mediante Lampérez o debido a la difusión que las ideas del teórico inglés estaban experimentando en España, conocía, al menos, una parte de sus reflexiones. Ha de tenerse en cuenta también que la influencia de John Ruskin fue recibida en Asturias por Adolfo Álvarez Buylla y Adolfo Posada ${ }^{35}$, que difundieron sus obras, y Leopoldo Alas "Clarín", integrantes del Grupo de Oviedo con el que Selgas mantenía una estrecha relación.

Frente a los antirrestauradores, Selgas situaba a los partidarios de la restauración, que eran aquellos que:

quieren la restauración del monumento, dejándole tal cual estaba como cuando fué erigido, para lo cual hay que derribar lo que no pertenezca a la primitiva fábrica y rehacer la parte derruida, imitando fielmente la antigua, devolviéndole su integridad y su estilo; pero si las construcciones levantadas con posterioridad a la erección del monumento pertenecen a otros géneros arquitectónicos, hay que respetarlas y conservarlas. Acto de vandalismo sería la destrucción del famoso transparente de la Catedral de Toledo, porque sus formas churriguerescas no se armonizan con la de aquel ingente monumento ${ }^{36}$.

Es evidente que compartía con Lampérez la necesidad de la imposición de ciertos límites a las restauraciones estilísticas, pero también expuso una ardiente defensa de Viollet-le-Duc y sus intervenciones en Notre-Dame de París, el castillo de Pierrefonds o la ciudadela de Carcasona. Asimismo, mantuvo la división de Cloquet, recibida a través de Lampérez, entre monumentos vivos y monumentos muertos y señaló la necesidad de intervenir en los primeros. Entre ellos, sin duda, se encontraba San Julián de los Prados, y por ello Selgas encontraba plenamente justificada su intervención:

Si estos monumentos, llamados muertos porque no pueden tener uso en nuestros días, se les restaura, en consideración a ser restos vivientes de otras civilizaciones, con mayor motivo debe hacerse con los vivos, es decir, con los que están hoy cumpliendo el fin para que fueron fundados, como la basílica de Santullano, que está abierta al culto once siglos hace y ha de continuar celebrándose ante sus altares algunos más, gracias a las obras de restauración realizadas, que le aseguran una larga vida ${ }^{37}$.

A la hora de proponer ejemplos que avalaran la metodología que había aplicado en Santullano, Selgas hizo referencia a restauradores que propusieron doctrinas diversas:

No he hecho más que seguir el camino abierto por los arquitectos extranjeros y españoles, que, con buen acierto, han preferido devolver a los monumentos su primitivo aspecto a verlos convertidos en ruinas, pudiendo citar en nuestro país a los Sres. Madrazo y D. Demetrio de los Ríos en la Catedral de León, Lampérez, en las de Burgos y Cuenca, Casanova en la de Sevilla y Velázquez Bosco en la Mezquita de Córdoba y en Santa Cristina de Lena ${ }^{38}$.

Es evidente que, al aludir a Madrazo, Demetrio de los Ríos y Lampérez, Selgas estaba manifestando su relación con la restauración estilística, con todos los matices que quedaron señalados, pero, por otro lado, Ricardo Velázquez Bosco, como es bien sabido, introdujo una nueva visión

\footnotetext{
${ }^{34}$ Selgas, 1916: 2-3.

${ }^{35}$ Litvack, 1990: 71.

36 Selgas, 1916: 3 .

${ }^{37}$ Selgas, 1916: 4

38 Selgas, 1916: 4
} 
que adelantó la renovación metodológica de la restauración española, previa a la asimilación de la restauración científica. No es menos interesante señalar que Selgas mencionó el precedente de la intervención en santa Cristina de Lena. Velázquez Bosco había propuesto una restauración que no pudo llevar a cabo, pero que Selgas conocía perfectamente, puesto que pertenecía a la Comisión Provincial de Monumentos y fue ese órgano el que propició y alentó la recuperación del supuesto estado original del templo, que finalmente fue materializada por Juan Bautista Lázaro ${ }^{39}$. En esta iglesia se había efectuado la reconstrucción de la bóveda que suponía la refacción de un supuesto elemento original desaparecido, basándose en criterios filológicos ${ }^{40}$. Pero también se plasmaron algunas soluciones que han pasado desapercibidas, pero que muestran la introducción puntual de una nueva metodología. El ángulo suroeste estaba muy deteriorado y fue preciso rehacerlo ${ }^{41}$. Aún hoy es visible esa intervención puntual, que quedó fielmente reflejada en una imagen que ilustra la monografía editada por Lázaro sobre sus intervenciones en la iglesia [fig. 2]. Es interesante observar que el remate del contrafuerte se repuso mediante una pieza muy simple, que no imita a las originales. Ese matiz permite identificar la reconstrucción parcial que experimentó el edificio y responde al criterio de identificar las restauraciones que ya había expuesto Lampérez.

Selgas no dudó en eliminar todas las estratificaciones históricas, pero lo justificó al señalar que esa decisión obedecía tanto a su falta de interés, como a la voluntad de recuperar un ejemplo señero de la arquitectura altomedieval asturiana. Por otro lado, basó sus decisiones en un análisis del edificio, de manera que ese conocimiento cimentó todas las operaciones que llevó a cabo y también le permitió revisar sus tesis anteriores a la restauración. Por ello, su intervención se convirtió en un proceso que contribuyó al conocimiento del monumento y sustentó decisiones como la plasmación del aspecto definitivo del pórtico. Además, elaboró una memoria final en la que integró documentos fotográficos y que, en conjunto, nos permite identificar toda la restauración, de manera que siguió la propuesta de Camilo Boito, quien señalaba la necesidad de componer esta documentación. Finalmente, el aspecto final de Santullano no puede comprenderse sin tener en cuenta el contexto estético del momento. El peso del ruinismo, el decadentismo y lo que se ha definido como la sinceridad arqueológica, se plasmó, como veremos, en un resultado final que exalta los efectos del paso del tiempo y la sugestión por la decadencia.

\section{La intervención en San Julián de los Prados}

Fortunato de Selgas, animado por la Comisión de Monumentos y especialmente por Fermín Canella, inició la restauración de la iglesia porque, al no haber sido declarada Monumento Nacional, se podía intervenir en ella sin el control de la Academia. Por ese motivo, el proyecto fue aprobado por la Comisión, el Obispo de Oviedo y el arquitecto diocesano ${ }^{42}$. Si bien se ha especulado con que Lampérez fuera en realidad el autor intelectual de la restauración, podemos pensar que pudo no ser así. Tal y como ya señaló en su momento Manzanares ${ }^{43}$, la idea de restaurar Santullano partió de Selgas y los comisionados. Además, en el informe que Lampérez presentó a la Academia para la declaración monumental de la iglesia, no se relaciona a sí mismo con las obras efectuadas. Al contrario, las ensalza y señala como obra de Selgas ${ }^{44}$. No tiene mucho sentido que hubiera ocultado su participación en el proyecto y, por tanto, podemos dudar razonablemente de la hipótesis que lo identifica como autor del mismo. Además, la dirección material de las obras la llevó a cabo personalmente Fortunato de Selgas, que en su memoria habla siempre en primera

\footnotetext{
39 García, 1999: 60-63.

40 García, 1999.

41 Lázaro, 1894: 21-22.

42 García, 1999: 91.

43 Manzanares, 1990: IX-XIV.

44 García, 1999: 91.
} 


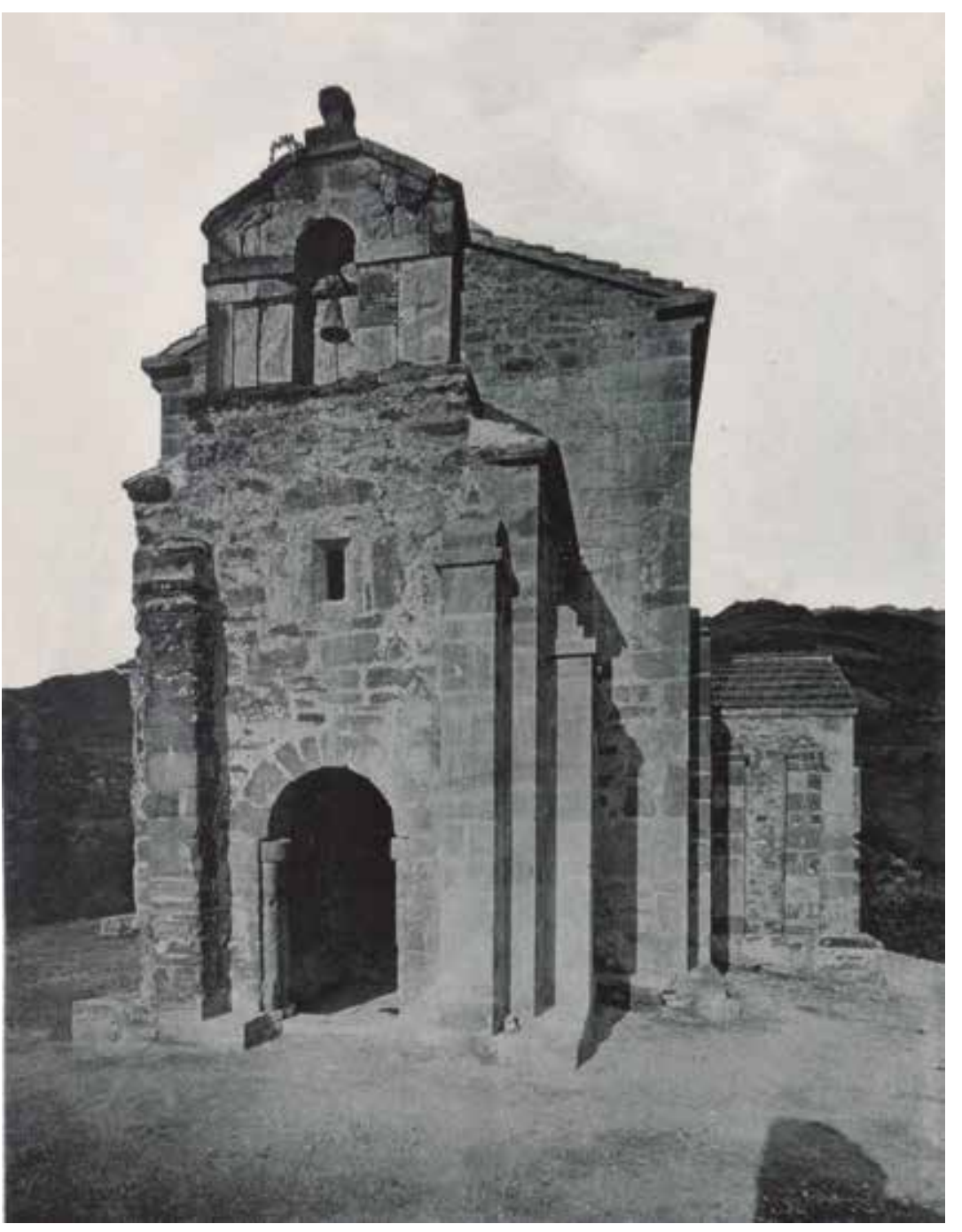

Fig. 2. Fachada de santa Cristina de Lena tras la restauración de Juan Bautista Lázaro. Se observa la refacción del ángulo suroeste, respetando el principio de la notoriedad de la restauración. Fuente: Lázaro, Juan Bautista (1894). Santa Cristina de Lena (Oviedo). Reseña de las obras hechas para su restauración.

persona y se atribuye la responsabilidad de todos los posibles errores en las decisiones adoptadas en el proceso de restauración.

En definitiva, la propuesta de Selgas puede calificarse de mínima, si bien la iglesia se transformó completamente. Propuso eliminar todos los añadidos que ocultaban la estructura altomedieval: "si se quitara el miserable pórtico que asombra la fachada principal; si se derribaran las bóvedas tabicadas del siglo XVIII que cubren las naves, y en vez de los churriguerescos retablos de los ábsides se alzaran las mesas de los altares, aisladas, podríamos contemplar la vieja basílica tal cual estaba cuando Alfonso el Casto la levantó" ${ }^{\prime 4}$. Entendía Selgas que era una operación sencilla puesto que se trataba más de derribar, que de construir y seguía el principio establecido por Lampérez: "Los monumentos arquitectónicos son «tipos» expresivos de cada época, y su «estilo» manifiesta, por modo indudable, la civilización de cada pueblo. Son, pues, documentos de inapreciable valor histórico" ${ }^{46}$. Por ese motivo, Santullano debía recuperar su estado original, aquel que la convertiría en un modelo de iglesia del período de la Monarquía Asturiana. Esto justificaba la depuración:

\footnotetext{
${ }^{45}$ Selgas, 1916: 1 .
}

${ }^{46}$ Selgas, 1916: 98. 
Fig. 3. Planta de San Julián de los Prados antes de su restauración. José M. ${ }^{a}$ Flórez González, 1874. Se señalan los elementos añadidos, como el antepórtico y la sacristía situada en el costado meridional.

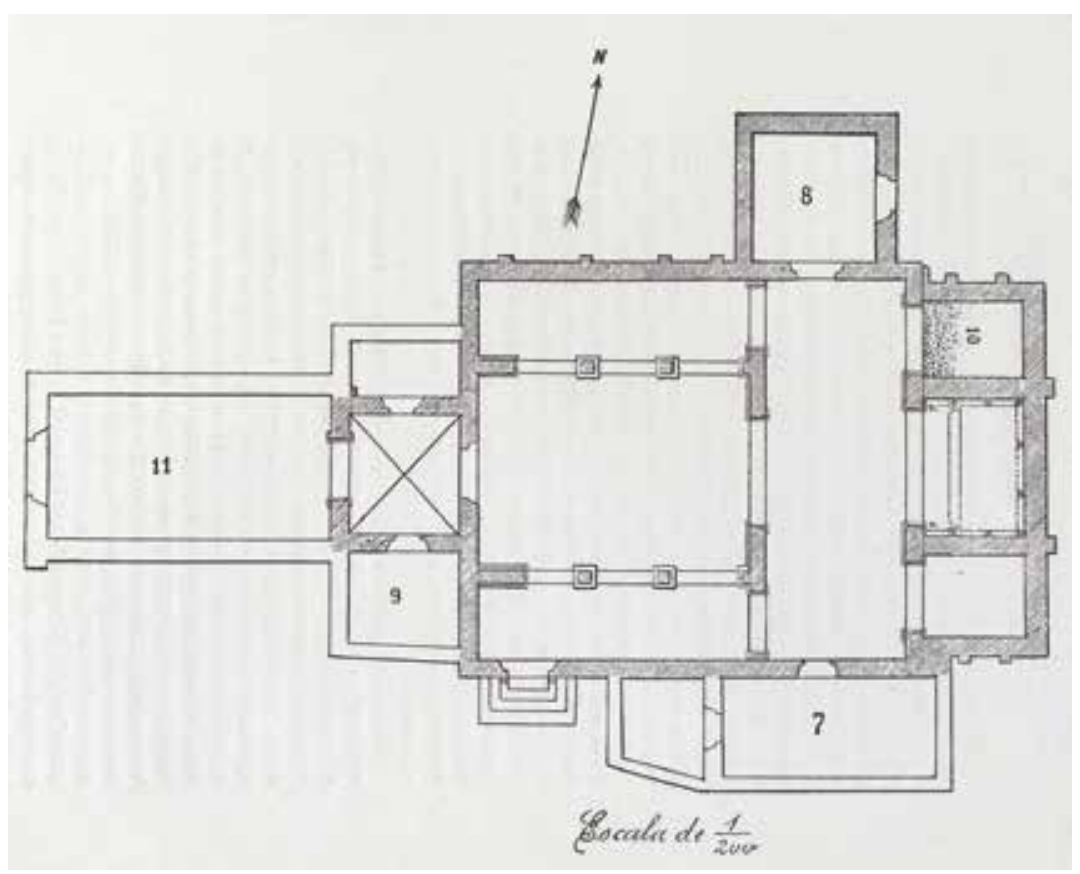

"El valor histórico de este monumento, resto viviente de una civilización de la que apenas nos dan noticias las concisas y descarnadas crónicas contemporáneas y los testamentos reales, y la importancia de sus formas arquitectónicas, en las que se refleja la manera de construir en la época más desdichada de la historia del Arte, me han decidido a devolverle su primitivo estado"47.

Fortunato de Selgas conocía los monumentos prerrománicos asturianos y sus investigaciones son inseparables de la actividad que desarrollaron los miembros de la Comisión de Monumentos y de la Academia de la Quintana ${ }^{48}$. Esa labor se plasmó en la edición de los primeros estudios sobre el prerrománico asturiano basados en el racionalismo arqueológico. En 1874 José M. ${ }^{a}$ Flórez González elaboró para la Comisión un primer análisis de Santullano ${ }^{49}$, que se acompañó de una planta que refleja su estado previo a la restauración [fig.3]. En 1904 se publicó Iglesias Primitivas de Asturias, obra de Inocencio Redondo, también comisionado. Redondo ${ }^{50}$ describió San Julián de los Prados como un edificio de gran austeridad exterior, cuya única decoración notable serían los canecillos que aparecen en los ángulos de los muros, las celosías y la ventana trífora suprabsidal. Señalaba lo exquisito de su composición y la articulación de sus volúmenes, que se escondería tras la apariencia de una iglesia rural y, precisamente por ello, opinaba que la existencia de la cámara suprabsidal se debe a la necesidad de equilibrar los volúmenes de la cabecera en relación con el potente crucero. Redondo realizó un análisis para discernir la estructura original del templo y aportó en su monografía una planta y una sección del mismo, señalando que las cubiertas abovedadas que presentaba a principios del siglo XX eran resultado de una reforma. No obstante, se planteaba la posibilidad de que las naves laterales hubieran podido estar cubiertas mediante bóvedas de arista. Su interés se centró en la decoración del ábside, con capiteles "muy semejantes á los que se conceptúan como visigodos en Andalucía, Extremadura, Toledo, Palencia, León y Aragón" ${ }^{51}$ y en la que también identificó la herencia de la romanidad.

\footnotetext{
${ }^{47}$ Selgas, 1916: 2.

48 García, 1999: 43-44 y García, 2017: 327-328.

49 García, 1999: 74.

${ }^{50}$ Redondo, 1904: 35-44.

${ }^{51}$ Redondo, 1904: 42.
} 


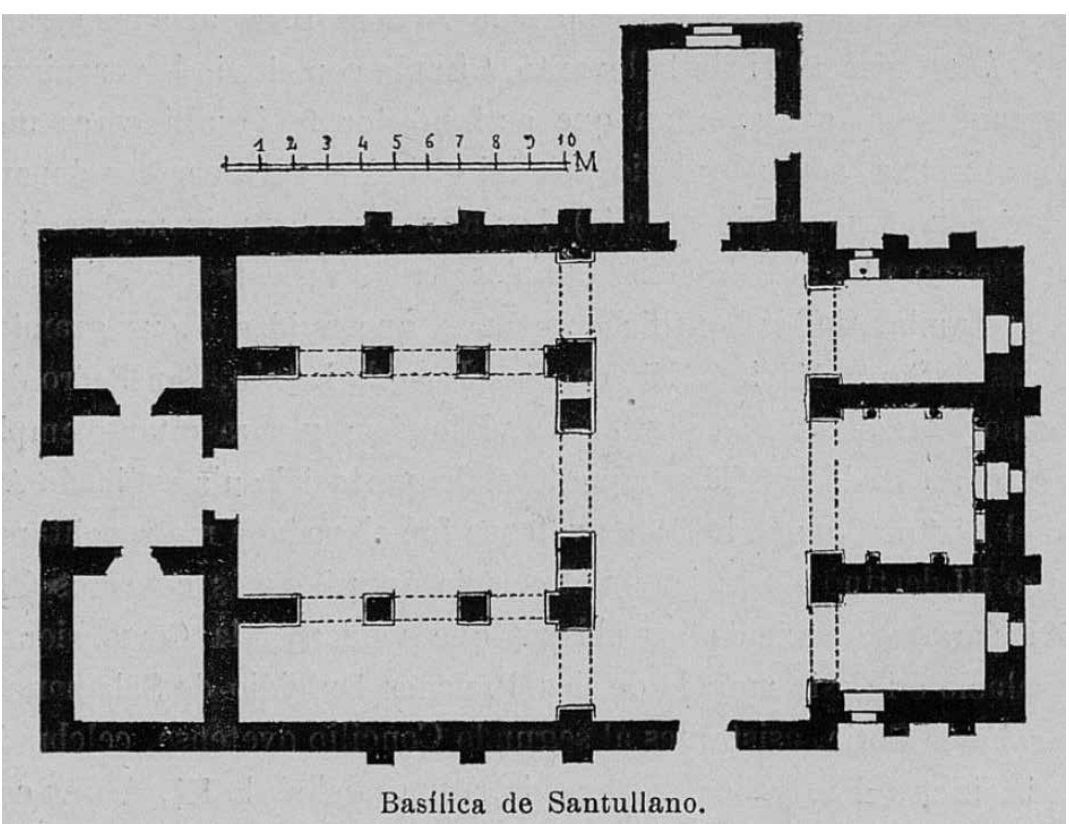

Fig. 4. Planta de San Julián de los Prados, según Fortunato de Selgas, 1908. Siguiendo a Redondo, Selgas aceptaba la existencia de un triple pórtico.

Cuatro años después, en 1908, apareció Monumentos ovetenses del siglo IX, un trabajo de Fortunato de Selgas que reunía varios artículos suyos publicados en el Boletín de la Sociedad Española de Excursiones. Selgas lamentaba que Santullano no hubiera sido incluida en la obra Monumentos Arquitectónicos de España, en la que sí figuraron el resto de las iglesias prerrománicas asturianas. La describe como la mejor conservada de todas las ovetenses y señalaba, cuatro años antes de llevarlas a cabo, las intervenciones que le devolverían su aspecto primitivo y que ya se señalaron anteriormente ${ }^{52}$. Elaboró una planta de la iglesia [fig. 4] que mantuvo la propuesta de Redondo, si bien eliminó la dependencia meridional del crucero, puesto que había sido sustituida por una sacristía de época moderna y no se podía contrastar su existencia, como exigía el racionalismo arqueológico que sustentaba sus investigaciones. Consideraba en este momento que tal dependencia no había existido. También es interesante señalar que creía que el edificio estaba precedido de un triple nártex. Definió la estructura basilical de Santullano como un tipo perfecto en su género y fue precisamente esa disposición modélica la que le devolvió con su restauración. Asimismo, observó la existencia de restos pictóricos bajo las sucesivas capas de cal, indicio que le llevó finalmente a eliminarlas para descubrir los frescos prerrománicos.

Fortunato de Selgas envió su obra a Jean-Auguste Brutails y ese ejemplar se conserva en el archivo de la Universidad Michel de Montaigne, junto a una carta autógrafa del asturiano fechada el 22 de junio de $1910^{53}$ en la que lamentaba su retraso en responder a una misiva anterior del arqueólogo francés, le agradecía que le hubiese enviado la Guide du Congrés de Carcassonne ${ }^{54}$ y definía los monumentos prerrománicos asturianos como unas humildes iglesias con más valor histórico que arqueológico. Otro dato relevante que nos aporta la lectura de este documento es que Brutails habría efectuado un viaje a Asturias y concretamente a Oviedo, puesto que Selgas lo cita. Curiosamente, esa visita tuvo lugar en 1908, coincidiendo con la edición del libro.

52 Selgas, 1908: 95 .

53 Carta de Fortunato de Selgas a Auguste Brutails, 22 de junio de 1910. 1886. Collections Patrimoniales numérisées de Bordeaux Montaigne, Burdeos, Universidad Bordeaux Montaigne, Identifiant(s) IL 18515. En: http://1886.ubordeaux-montaigne.fr/items/show/10144 [19/05/2019]

${ }^{54}$ Esta obra fue editada en 1906. Lahondés, Jules. Serbat, Louis. Thiers, Paul. Brutails, Auguste (1906): Guide du Congrés de Carcassonne.Caen. Société Française d'Archéologie. 
Fig. 5. Planta de San Julián de los Prados, según Fortunato de Selgas, 1916. Tras el estudio de la iglesia, estableció la hipótesis de la existencia de un pórtico sin dependencias laterales.

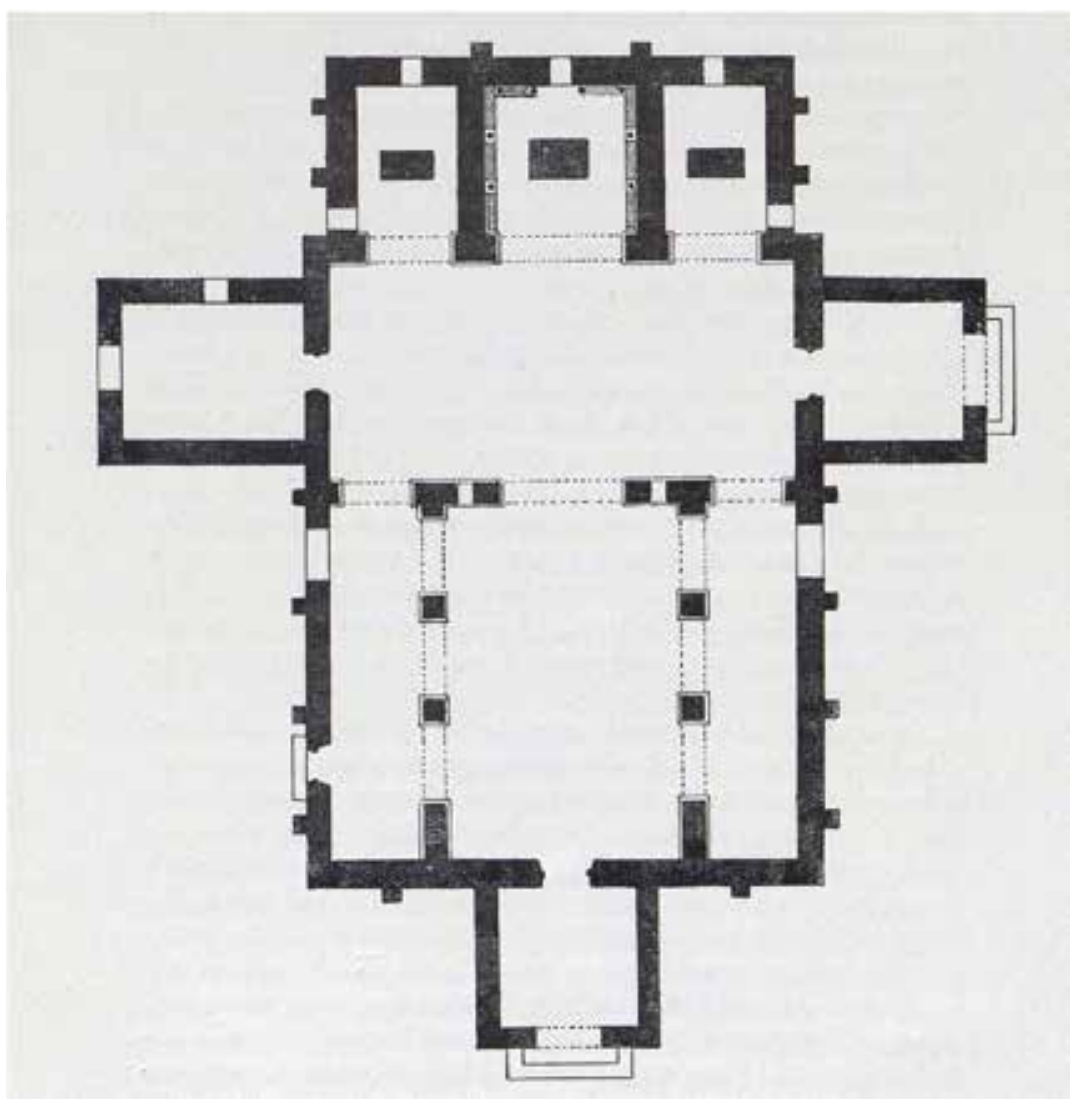

Selgas intervino en Santullano entre el 9 de noviembre de 1912 y el 8 de mayo de $1915^{55}$ y, tal y como había apuntado en 1908, eliminó todos los añadidos posteriores a la fase altomedieval. Consideraba que carecían de calidad y que oscurecían lo realmente fundamental de la iglesia: "No se han hecho en la basílica de Santullano, del siglo IX en adelante, obras de restauración que lleven el sello del arte" ${ }^{96}$. Los trabajos de restauración fueron precedidos de nuevos estudios, que mejoraron su conocimiento del monumento. Localizó en el libro de fábrica datos que le permitieron establecer que la sacristía se había asentado sobre una dependencia lateral, que no había contemplado en 1908. Asimismo, identificó el arranque de los muros de esa estructura y en el sótano situado bajo la nueva sacristía localizó todos los materiales de sillería procedentes de su derribo "sin faltar uno" 57 : las basas de las pilastras, las jambas, las impostas, las ménsulas del alero y parte del sillarejo de las esquinas. Hechos estos descubrimientos, consideró justificado rehacer ese espacio y devolver al flanco de la iglesia su aspecto original, ya que contaba con los elementos necesarios para hacerlo: "Existiendo todos los elementos constructivos, los cimientos de la fachada y los muros laterales hasta cierta altura, me pareció conveniente alzarle de nuevo, o más bien armarle, como así se ha hecho, viéndose hoy esta parte de la basílica tal cual estaba en el siglo IX"58. Asimismo, tras efectuar un análisis del mismo, Selgas decidió que el imafronte del templo no estaba precedido de un triple nártex [fig. 5], como había afirmado en 1908, sino de un pórtico cuadrado y derribó tanto el antepórtico, como las dependencias laterales [figs. 6 y 7].

\footnotetext{
55 Selgas, 1916: 65.

56 Selgas, 1916: 4.

${ }^{57}$ Selgas, 1916: 22.

58 Selgas, 1916: 23.
} 

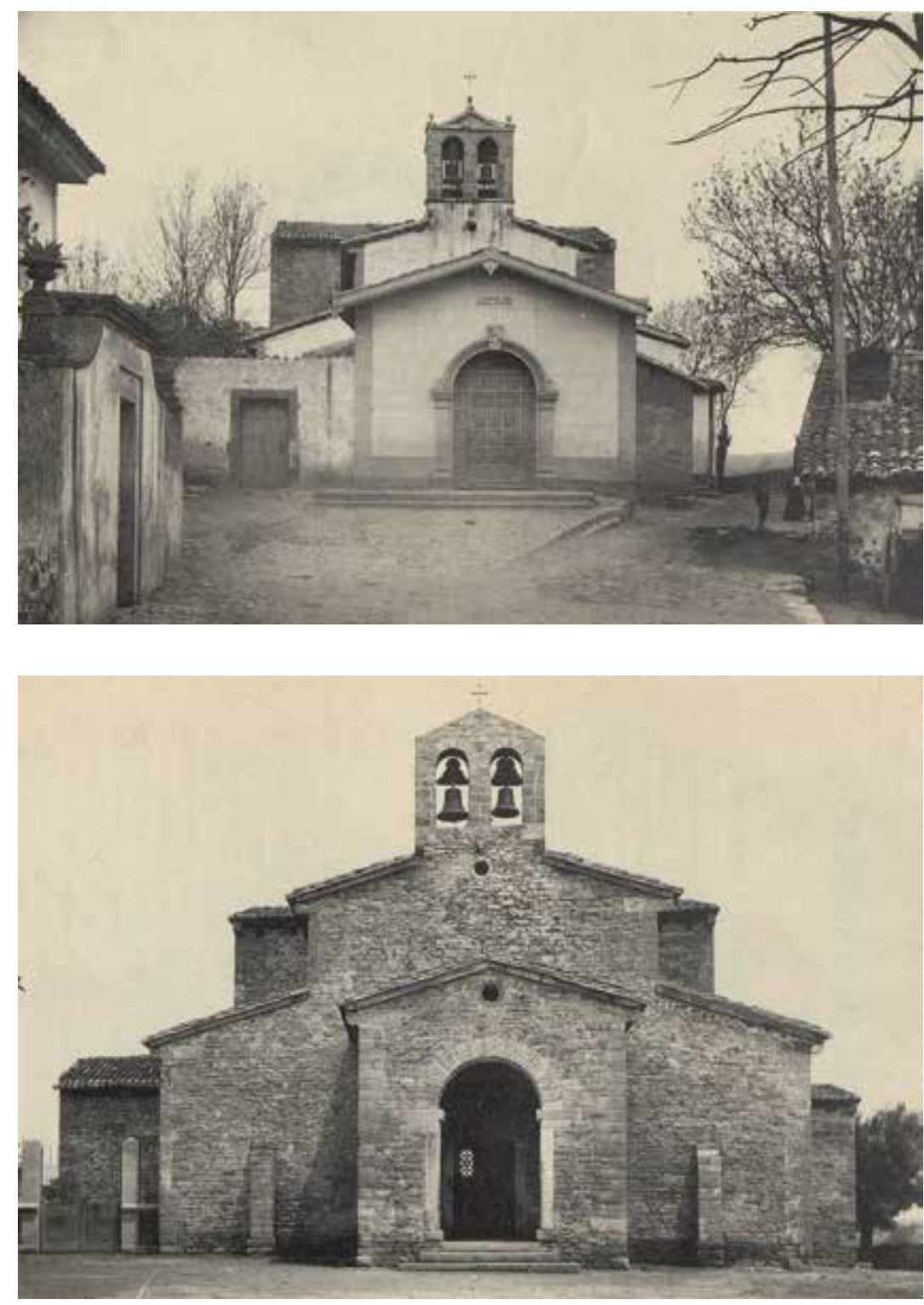

Fig. 6. Santullano. Imafronte antes de la restauración. Se observa en primer término el antepórtico y en segundo plano las dependencias que flanqueaban el pórtico y que hicieron suponer la existencia de un triple nártex. Fotografía, publicada por Fortunato de Selgas.
Fig. 7. Santullano. Imafronte después de la restauración. Se han desencalado los muros, se han eliminado el antepórtico y las dependencias laterales del nártex y se ha restaurado la espadaña. Fotografía, publicada por Fortunato de Selgas.

También eliminó las bóvedas introducidas en el siglo XVII y una vez derribadas, devolvió a los vanos su altura original y colocó en ellos reproducciones de celosías, cuyo diseño se atribuye a Vicente Lampérez, y que están inspiradas en los modelos de santa María del Naranco, san Miguel de Lillo y san Salvador de Valdediós. También se reprodujeron las que cerraban las ventanas de los ábsides central y de la epístola, imitando la original que se conservaba en el del evangelio ${ }^{59}$. La cubierta de la iglesia se encontraba en muy mal estado y había sido repuesta con materiales de poca calidad en el siglo XVIII, ya que iba a quedar oculta por las nuevas bóvedas que se construyeron en ese momento. Selgas la describió como más propia de un establo que de un templo. De la estructura original, se pudieron recuperar tres vigas del crucero, que se dejaron en su lugar, y los fragmentos de las medievales que pudieron reaprovecharse

59 Selgas, 1916: 40. 
Fig. 8. Santullano. Interior antes de la restauración, con los muros encalados y las bóvedas añadidas en el siglo XVIII. Fotografia publicada por Fortunato de Selgas.

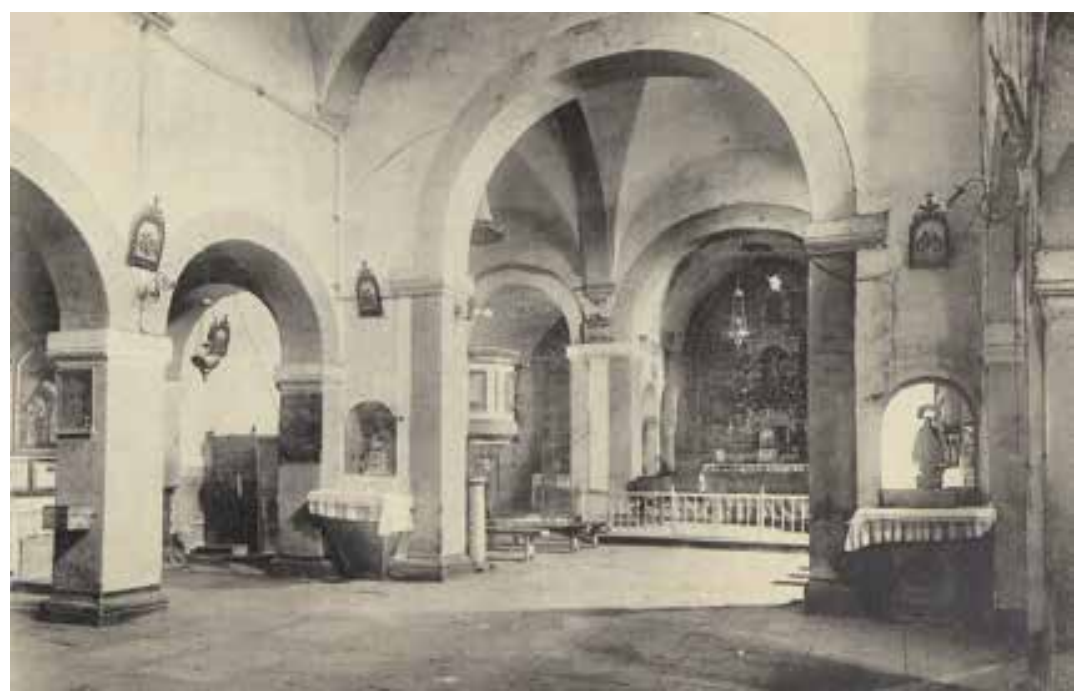

Fig. 9. Santullano. Interior después de la restauración (1932) con los muros desencalados, las huellas de las bóvedas y la armadura restaurada. Bildarchiv. Foto Marburg.

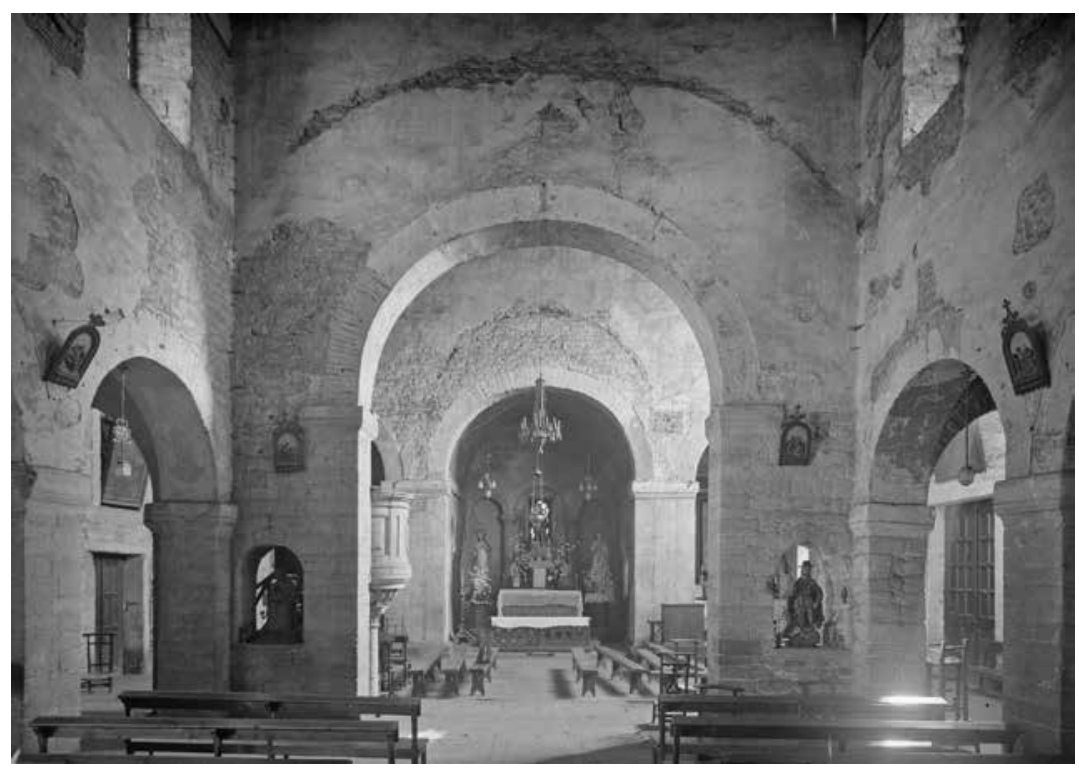

se colocaron en el pórtico, facilitando la visión de su decoración pictórica. Además, las vigas de las naves que se mantuvieron en su emplazamiento original, fueron aisladas de la humedad procedente del tejado colocando un lecho de rasilla y cemento. Selgas aceptó la integración de materiales contemporáneos siempre que sirvieran a la conservación del monumento y no fuesen visibles ${ }^{60}$. También opinaba que Santullano habría contado con una espadaña original, que fue sustituida por otra de estilo románico sostenida por una imposta y tres canecillos, elementos que decidió conservar por su "carácter artístico". En cambio, eliminó el remate de época moderna que se le había añadido ${ }^{61}$.

Al proceder a la limpieza interior de los muros y al derribo de las bóvedas, descubrió los frescos prerrománicos, que habían sido dañados al colocar las bóvedas del siglo XVIII. Ante

60 Selgas, 1916: 44-47.

${ }^{61}$ Selgas, 1916: 49-50. 


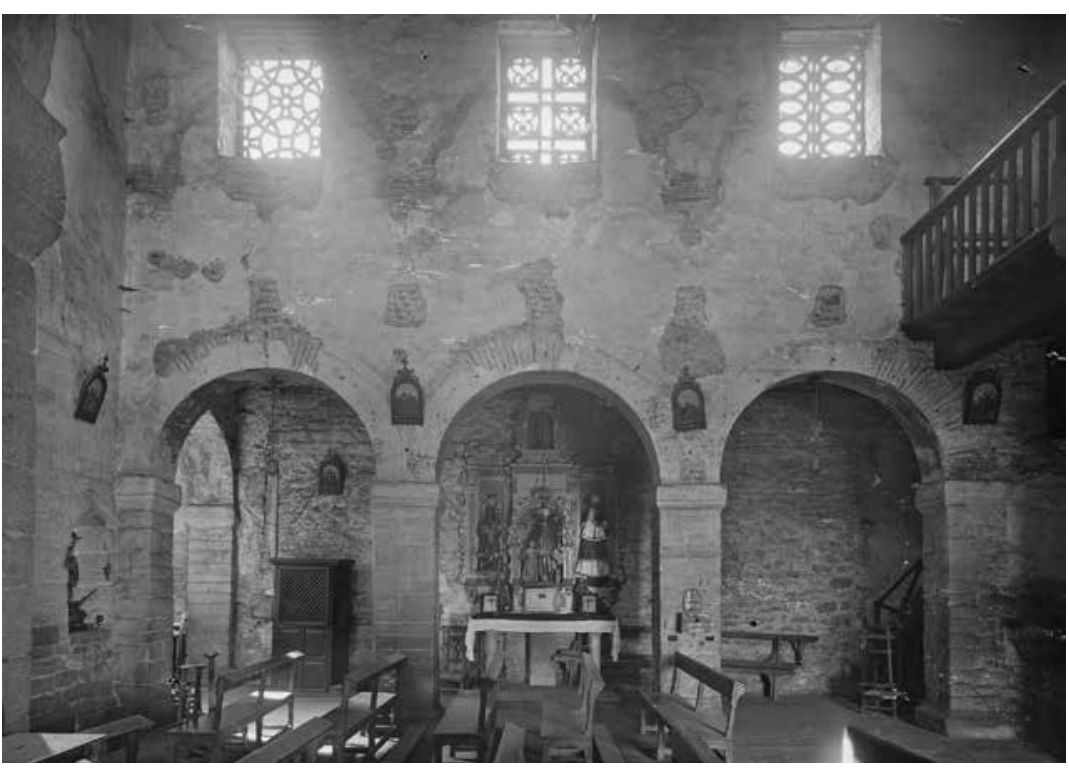

Fig. 10. Santullano. Interior de la nave central hacia la arquería meridional después de la restauración (1932). Se evidencian la estética ruinista y la sinceridad arqueológica. Son visibles la huella de las bóvedas, los vanos restaurados y las celosías repuestas. Bildarchiv. Foto Marburg.

esta situación, Selgas tomó una decisión que se relaciona directamente con la estética ruinista, puesto que optó por dejar a la vista esas cicatrices [figs. 8 y 9]. El aspecto de la iglesia en ese momento evidenciaba y enfatizaba los efectos del paso del tiempo, las reformas y la restauración. Se podía percibir que uno de los estratos históricos había sido eliminado al ser visibles las huellas de esa operación. Selgas explicó cuál había sido el objetivo que guio esa elección: "La silueta curva de los lunetos está marcada con surcos abiertos en el cemento hasta la mampostería, y se han dejado a la vista porque dan a las naves un aspecto de vetustez y de ruina propio de un edificio que lleva tantos siglos de vida" ${ }^{62}$. De esa manera, dejó clara su voluntad de evocar el aspecto de ruina en el interior del monumento. Asimiló el valor histórico, la historia acumulada, con el efecto del mismo y las manifestaciones físicas de ese proceso [fig. 10]. La restauración tuvo como resultado la transformación del interior de la iglesia influenciada por el ruinismo y el decadentismo que marcaban el contexto cultural del momento. Selgas incorporó en su monografía unas fototipias que enfatizan, e incluso exageran, esa imagen de decadencia y ruina del edificio [figs. 11 y 12]. Lamentablemente, ese aspecto fue borrado en las posteriores restauraciones de la iglesia. Hoy podemos conocerlo mediante unas fotografías inéditas de 1932, correspondientes a la campaña que Richard Hamann emprendió en España, Francia e Italia ${ }^{63}$ y que nos permiten constatar esa imagen perdida y destruida como resultado de nuevas intervenciones. La falta de aprecio y de respeto por la restauración precedente y por la imagen fijada por la actuación de Selgas, nos ha hecho perder uno de los testimonios más interesantes, por su riqueza de matices, de la historia de la restauración del siglo XX en España.

Selgas aplicó también principios propios de la metodología defendida por Boito: estudio histórico, limpieza de paramentos, excavaciones, establecimiento de la hipótesis de estado original del monumento, recuperación de elementos originales, documentación de la intervención mediante fotografías y publicación de una monografía que explica todas sus actuaciones, acompañada de imágenes que permitían comprender el alcance de sus trabajos. Para finalizar esa publicación, anotó minuciosamente las obras nuevas que había llevado a cabo: construcción del pórtico me-

\footnotetext{
${ }^{62}$ Selgas, 1916: 54.
}

${ }^{63}$ Laupichler, 2016: 43. 


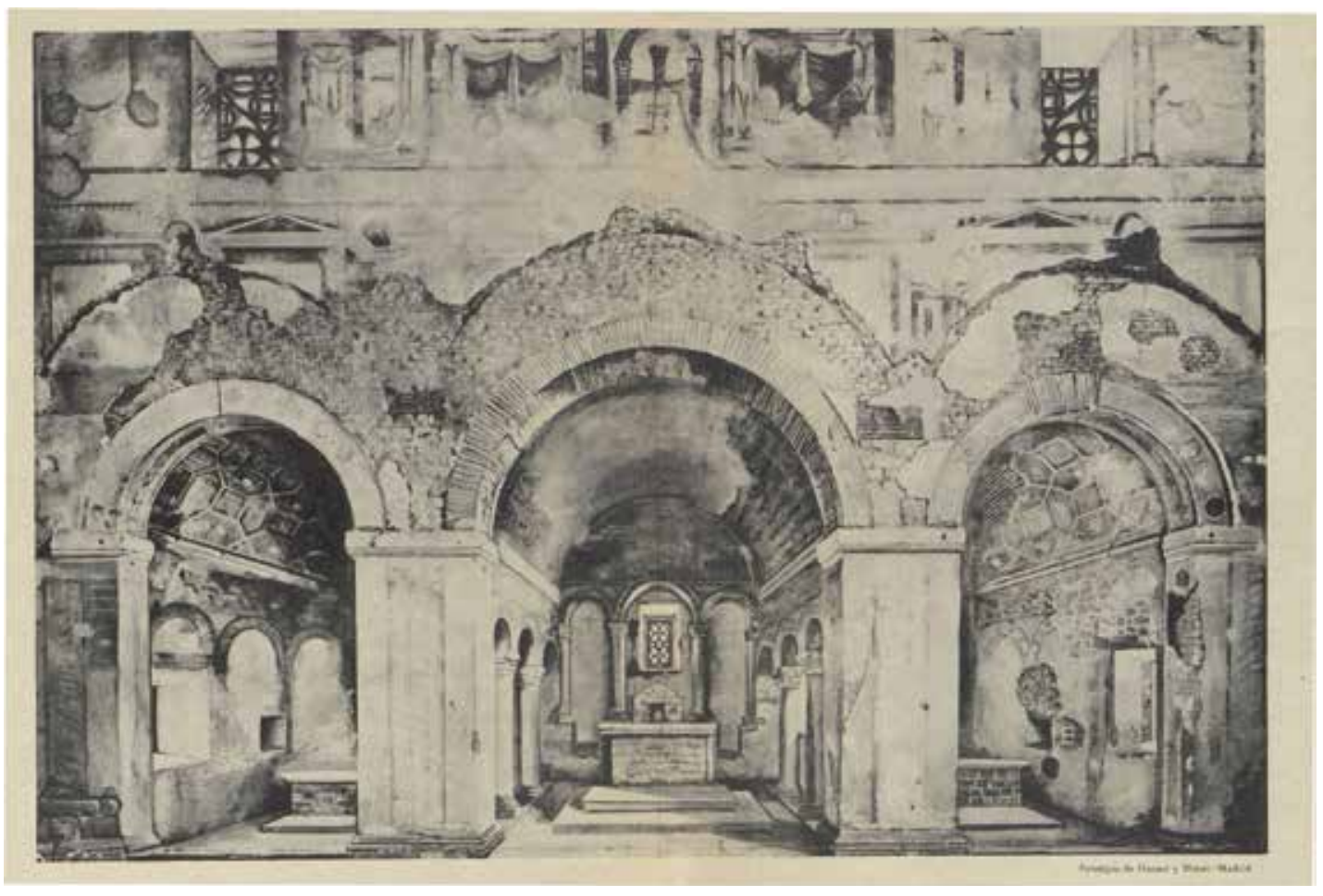

Fig. 11. Santullano. Vista interior del frente de los ábsides tras la restauración. La fototipia publicada por Fortunato de Selgas enfatiza el aspecto de decadencia y ruina del monumento.

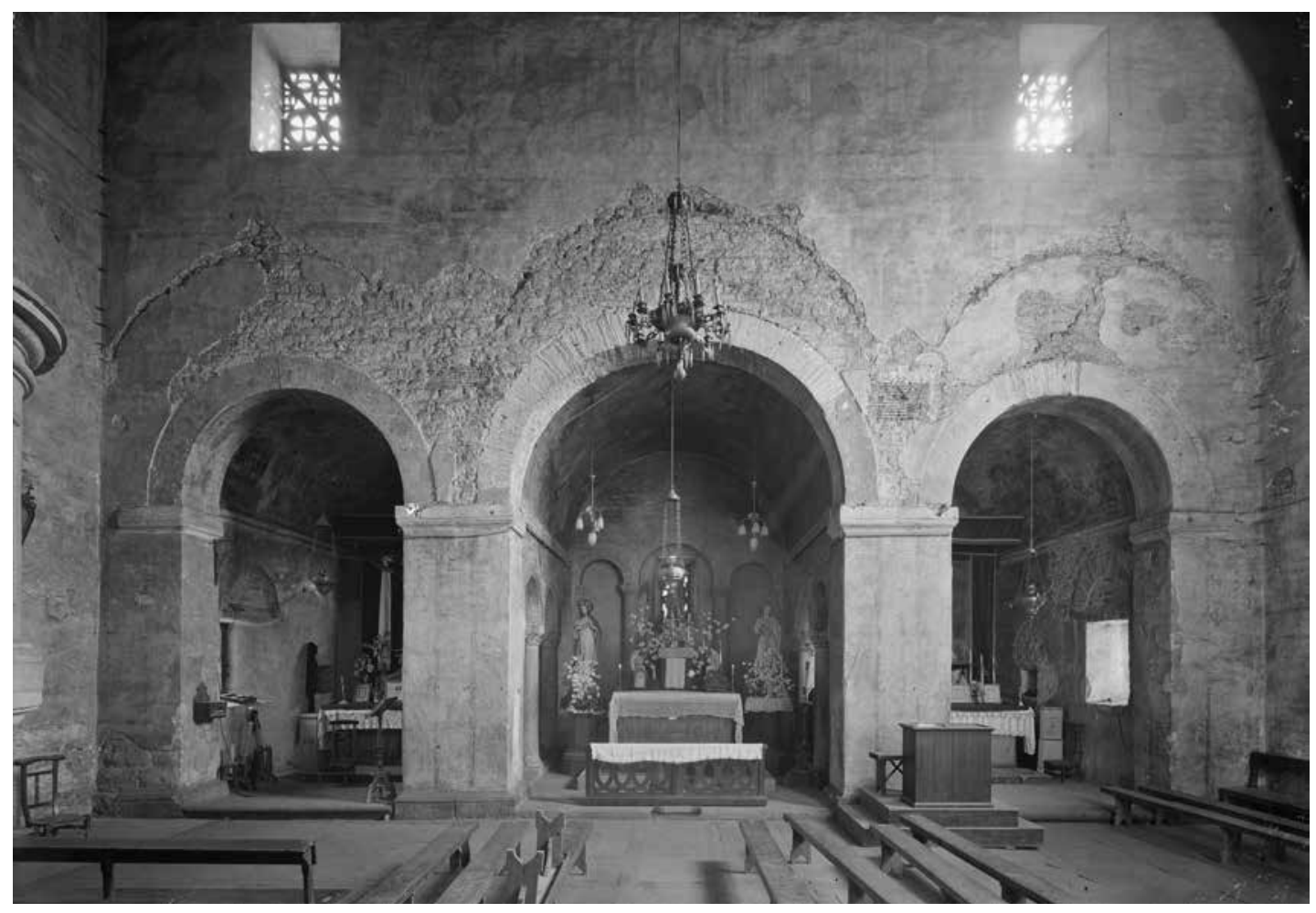

Fig. 12. Santullano. Vista interior del frente de los ábsides. La fotografía de 1932 puede compararse con la imagen anterior, en la que la estética ruinista se enfatiza. Bildarchiv. Foto Marburg. 
ridional; celosías de las naves y el crucero, excepto la original del ábside de poniente y del gran vano meridional del transepto en el que colocó un cierre de vidrio; cubierta de las naves y el crucero; los tres altares de los ábsides, aprovechando algunas losas de los originales que se habían conservado; la mitad superior de la espadaña y el coro alto de madera, que ya había sido rehecho en el siglo XVIII.

Pese a todo, Selgas no consiguió completar el proceso de devolver a la iglesia su carácter de hito de la arquitectura de la monarquía asturiana. Era partidario de depurar su interior de todo aquello que no se correspondiese con la imagen altomedieval, que fuera declarada Monumento Nacional y se construyera una nueva parroquia, reservando el templo prerrománico para la recuperación del rito mozárabe. La restauración material debía unirse a la restauración litúrgica:

Para devolverle su carácter primitivo habría que desterrar de sus naves esos altares y retablos y llevarlos a una nueva iglesia parroquial, que debe hacerse de mayores proporciones, y allí se podrían exhibir con sus imágenes vestidas, sus exvotos de brazos y piernas de cera, coletas de pelo, flores de trapo y retratos de lienzo y fotografía, que no se conocían en tiempo de Alfonso el Casto. El viejo templo continuaría dedicado al culto, y ante sus altares; se elevarían preces a los Santos Julián y Basilisa, no interrumpidas del siglo IX a nuestros días. Aunque parezca una lucubración mía, al par que la restauración del monumento debería hacerse la del rito visigodo que se celebraba en aquella época, concesión fácil de conseguir del Romano Pontífice, y así volveríamos a ver aunados en este templo el arte y el rito mozárabe como en los días de los Alfonsos y Ramiros ${ }^{64}$.

\section{Conclusiones}

La intervención de Fortunato de Selgas en Santullano es un ejemplo que sintetiza el debate sobre la restauración monumental en España a principios del siglo XX. Aglutina elementos de la restauración estilística, limitada por el racionalismo arqueológico, el avance de las teorías italianas de la restauración histórica y moderna y la influencia de la estética ruinista y de la sinceridad arqueológica.

En realidad, estas acciones no fueron entendidas como una restauración, puesto que se limitaron las recreaciones y se eliminaron aquellas estratificaciones que se consideraron lesivas para el monumento, pero se mantuvo la huella de las operaciones realizadas. Siguiendo los preceptos boitinanos, Selgas redactó una memoria que permite constatar el alcance de las intervenciones e identificar los elementos rehechos. Quizás la definición más precisa de todo este proceso sea la del informe emitido por Vicente Lampérez a la Real Academia de la Historia, que lo describe con el término reconstitución ${ }^{65}$. Sea como fuere, este ejemplo singular y cabe decir que fundamental para entender la historia de la restauración monumental en España, puede ser valorado finalmente mediante las fotografías que Richard Hamann y su equipo realizaron en $1932^{66}$. Son más nítidas y de mayor calidad que las publicadas hasta el momento. Permiten captar los detalles del acabado interior de los paramentos, del estado de las pinturas, recorrer tanto el interior, como todas las fachadas exteriores del templo y conocer el estado de la iglesia antes de la revolución de 1934, la guerra civil y las posteriores restauraciones que sufrió. Por todo ello, constituyen un documento precioso que nos acerca a una imagen casi desconocida de Santullano y nos devuelve muchos de los matices perdidos de la restauración de Fortunato de Selgas.

${ }^{64}$ Selgas, 1916: 5

${ }^{65}$ Lampérez, 1917: 326.

${ }^{66}$ En este momento trabajo en el montaje de una exposición que dará a conocer el conjunto completo de fotografías elaboradas por la expedición alemana. 


\section{BIBLIOGRAFÍA}

Arrechea de Miguel, Julio (1989): Arquitectura y Romanticismo. Valladolid: Universidad de Valladolid.

Ashworth, Gregory / Howard, Peter (1999): European Heritage, Planning and Management. Exeter, Intellect Books.

Bryon, Hilary (2009): "Measuring the qualities of Choisy's oblique and axonometric projections". En: Girón Sierra, Francisco Javier / Huerta Fernández, Santiago (eds.): Auguste Choisy (1841-1909). L'architecture et l'art de bâtir: actas del Simposio Internacional celebrado en Madrid, 19-20 de noviembre de 2009. Madrid: Instituto Juan de Herrera, pp. 31-62.

Capellán de Miguel, Gonzalo (2002): "Intelectuales, universidad y opinión pública. El grupo de Oviedo". En: Historia y Política, 8, pp. 9-37.

Chueca Goitia, Fernando (1984): “John Ruskin, un mito olvidado”. En: Cuenta y razón, 17, pp. 15-21.

Gallego Fernández, Pedro Luís (2000): "Vicente Lampérez. Arquitecto entre la arqueología y la modernidad”. En: Restauración \& Rehabilitación, 45, pp. 56-61.

García Cuetos, M. ${ }^{a}$ Pilar (1999): El prerrománico asturiano. Historia de la arquitectura y restauración (1844-1976). Oviedo: Sueve.

García Cuetos, M. ${ }^{\text {a }}$ Pilar (2011): "La renovación de la Historia de la Arquitectura y del Arte en las primeras décadas del siglo XX. Manuel Gómez-Moreno”. En: Biel Ibáñez, Pilar / Hernández Martínez, Ascensión (eds.): Lecciones de los maestros aproximación histórico-crítica a los grandes historiadores de la arquitectura española: [Seminario celebrado en Zaragoza los días 26, 27 y 28 de noviembre de 2009]. Zaragoza: Institución Fernando el Católico, pp. 125-158.

García Cuetos, M. ${ }^{a}$ Pilar (2016): El Lenguaje de las Bellas Construcciones. Reflexiones sobre la recepción y la restauración de la Arquitectura andalusí. Granada: Publicaciones de la Universidad de Granada.

García Cuetos, M. ${ }^{a}$ Pilar (2017): "El Prerrománico Asturiano. De arquitectura emblemática a patrimonio mundial. Recepción y restauración de una arquitectura singular". En: Cabañas, Miguel / Rincón, Wifredo (eds.): Imaginarios en conflicto. Lo Español en los siglos XIX y XX. Madrid: CSIC, pp. 325-343.

García Cuetos, M. ${ }^{a}$ Pilar (2019): “John Ruskin's legacy in the debate on monument restoration in Spain”. En: Restauro Archeologico. Memories on John Ruskin Unto this last special issue, 1, 2019, pp. 242-247.

Girón Sierra, Francisco J. / Gil Crespo, Ignacio (2009): "La influencia del dibujo de Choisy en España. Notas para su estudio”. En: Auguste Choisy (1841-1909). L'architecture et l'art de bâtir: actas del Simposio Internacional celebrado en Madrid, 19-20 de noviembre de 2009, Madrid: Instituto Juan de Herrera, pp. 235-260.

González Menéndez, Lucía / Fernández García, Ana M. a (1994): "La colección Selgas: Un modelo del coleccionismo finisecular español”. En: Espacio, Tiempo y Forma, Serie VII, Historia del Arte, t. 7, pp. 275-290.

Isac Martínez de Carvajal, Ángel (1987): Eclecticismo y pensamiento arquitectónico en España. Discursos, revistas, congresos 1846-1919. Granada: Editorial Universidad de Granada.

Lampérez y Romea, Vicente (1906): "La restauración de los monumentos arquitectónicos. Teorías y opiniones”. En: Arquitectura y Construcción, año XI, 177, pp. 97-108.

Lampérez y Romea, Vicente (1917): “La Basílica de San Julián y Santa Basilisa (Oviedo)”, B.R.A.H, LXX, 1917, pp. 325-331.

Laupichler, Fritz (2016): Das Bildarchiv Foto Marburg. Von der "Photographischen Gelleschaft" zum Deutschen Dokumentationszentrum für Kuntsgeschichte Ein historic-cronologischer Abriss 1913-2013. Marburg: Tectum Verlarg.

Lázaro, Juan Bautista (1894): Santa Cristina de Lena (Oviedo). Reseña de las obras hechas para su restauración. Madrid: Antero de Oteyza y Barinaga.

Litvak, Lily (1973): "Ruskin y el sentimiento de la naturaleza en las obras de Unamuno". En: Cuadernos de la Cátedra Miguel de Unamuno, 23, pp. 211-220.

Litvak, Lily (1985): “Exotismo arqueológico en la literatura española de finales del siglo XIX. 1880-1895”. En: Anales de Literatura Española, pp. 183-196.

Litvak, Lily (1990): España 1900. Modernismo, anarquismo y fin de siglo. Madrid: Anthropos.

Manzanares Rodríguez, Joaquín (1990): "Don Fortunato de Selgas y Albuerne y su restauración de Santullano de los Prados". Prólogo a la edición de Selgas Albuerne, Fortunato de (1916). La Basílica de San Julián de los Prados (Santullano) en Oviedo. Oviedo: Avízoras, pp. IX-XIV.

Navascués Palacio, Pedro (1978): “Arquitectura”. En: Navascués, Pedro / Pérez Reyes, Carlos / Arias de Cossío, Ana M. (eds.): Del Neoclasicismo al Modernismo, Historia del arte Hispánico, t. V. Madrid: Alhambra, pp. 1-146.

Puig i Cadafalch, Josep (1918): Santa Maria de la Seu d'Urgell: estudi monogràfic. Barcelona: Taller d'arts gràfiques Henrich i $\mathrm{C}^{\mathrm{a}}$.

Redondo Ibáñez, Inocencio (1904): Iglesias primitivas de Asturias. Oviedo: Comisión de Monumentos Históricos y Artísticos de la Provincia de Oviedo. 
Rivera Blanco, Javier (1992): "El Marqués de la Vega Inclán (1858-1942): Protector y restaurador de monumentos. In memoriam en el L aniversario de su fallecimiento". En: Boletín de la Real Academia de la Purísima Concepción de Valladolid, 27, pp. 31-61.

Rivera Blanco, Javier (2008): De varia restauratione. Teoría e Historia de la Restauración Arquitectónica. Madrid: Abada.

Rivera Blanco, Javier (2011): "El comienzo de la historia de la arquitectura en España, Vicente Lampérez y Romea". En: Biel Ibáñez, Pilar / Hernández Martínez, Ascensión (eds.): Lecciones de los maestros aproximación histórico-crítica a los grandes historiadores de la arquitectura española: [Seminario celebrado en Zaragoza los días 26, 27 y 28 de noviembre de 2009]. Zaragoza: Institución Fernando el Católico, pp. 59-90.

Ruskin, John (1900): Las Siete Lámparas de la Arquitectura. (El Sacrificio. La Verdad. La Fuerza. La Belleza. La Vida. El Recuerdo. La Obediencia) y La corona de olivo silvestre (El Trabajo. El Comercio La Guerra. Madrid: La España Moderna, 1900.

Selgas Albuerne, Fortunato de (1908): Monumentos Ovetenses del Siglo IX. Madrid: Imprenta de san Francisco de Sales. Selgas Albuerne, Fortunato de (1916): La Basílica de San Julián de los Prados (Santullano) en Oviedo, Estudio de las restauraciones efectuadas en 1912-1915. Madrid: Fototipia de Hauser y Menet.

Simón Palmer, M. ${ }^{a}$ del Carmen (2010): "Carmen de Burgos, traductora”. En: Arbor. Ciencia, Pensamiento y Cultura, CLXXXVI extra, pp. 157-168.

Fecha de recepción: 26-VI-2020

Fecha de aceptación: 05-XI-2020 